\title{
PARTISIPASI TENAGA KERJA WANITA DI USAHA BUNGA POTONG DI KELURAHAN KAKASKASEN II, KECAMATAN TOMOHON UTARA, KOTA TOMOHON
}

\author{
Verro Stevanus Tampun Worung \\ Charles R. Ngangi \\ Ellen G. Tangkere
}

\begin{abstract}
In this era of globalization, many efforts have done in order to earn money for the family. Efforts in agriculture be one choice of families and communities. In general, the development has opened up opportunities for women to engage in various businesses in the agricultural sector which has been dominated by men. The purpose of this study was to determine the participation of women owners or workers in the cut flower business in Kakaskasen II Village, North Tomohon sub district, Tomohon. The study lasted for 3 months, namely in November 2015 until January 2016, ranging from research preparation to the formulation of a research report. The data used in this study are primary and secondary data. Primary data was collected through direct interview to the respondents. Method of sample selection has used purposive sampling technique on nine women from 11 women as population who are owners or workers in the cut flower business. Data collection is a direct interview and observation (observation). Secondary data was collected from previous studies conducted by other researchers, but at the same location. Data analysis in this research using descriptive analysis and also using a Likert scale, with level 1 (underactive), 2 (active), 3 (highly active). This study found, based on an analysis using a Likert scale, that the number of female labor force participation index in the cut flower business (including planting, maintenance, cutting/ harvesting/buying, stringing, or sales) are at a point that $85.6 \%$ were categorized as high. Further analysis showed that the labor force participation rate of women in cut flower business with a score of up to 185 of the range of the number of ideal scoring the highest score was 216 and the lowest score was 72 . Suggestions in this study, based on the conclusions derived, is the government should open up more opportunities to increase the number of business opportunities and work for women in cut flower business in order to alleviate the problem of female unemployment and poverty that exist in Tomohon City. *eprm*
\end{abstract}

Keywords : participation, women, the cut flower business, Kakaskasen II Village,Tomohon City

\section{ABSTRAK}

Dalam era globalisasi, banyak upaya yang dilakukan dalam rangka untuk mendapatkan penghasilan untuk keluarga. Upaya di bidang pertanian menjadi salah satu pilihan dari keluarga dan masyarakat. Secara umum, upaya pembangunan telah membuka peluang bagi wanita untuk terlibat dalam berbagai usaha di sektor pertanian yang selama ini didominasi oleh laki-laki. Tujuan dari penelitian ini adalah untuk mengetahui partisipasi pemilik wanita atau pekerja pada usaha bunga potong di Kelurahan Kakaskasen II, Kecamatan Tomohon Utara, Kota Tomohon. Penelitian ini berlangsung selama 3 bulan, yaitu pada bulan November 2015 hingga Januari 2016, mulai dari persiapan penelitian untuk perumusan laporan penelitian. Data yang digunakan dalam penelitian ini adalah data primer dan sekunder. Data primer dikumpulkan melalui wawancara langsung kepada responden. Metode pemilihan sampel menggunakan tehnik purposive sampling pada sebanyak sembilan wanita dari populasi 11 yang merupakan pemilik atau pekerja pada bisnis bunga potong. Pengumpulan data yang digunakan adalah wawancara langsung dan observasi (pengamatan). Data sekunder dikumpulkan dari penelitian sebelumnya yang dilaksanakan oleh peneliti lain tetapi pada lokasi yang sama. Analisis data dalam penelitian ini menggunakan metode analisis deskriptif dan juga menggunakan skala Likert, dengan level 1 (kurang aktif), 2 (aktif), 3 (sangat aktif). Penelitian ini menemukan, berdasarkan analisis menggunakan skala Likert, bahwa jumlah indeks partisipasi angkatan kerja perempuan dalam usaha bunga potong (termasuk penanaman, pemeliharaan, pemotongan/panen/pembelian, merangkai, atau penjualan) berada pada $85,6 \%$ yang sehingga termasuk kategori tinggi. Analisis lebih lanjut menunjukkan bahwa tingkat partisipasi tenaga kerja perempuan dalam bisnis bunga potong pada skor 185 dari kisaran jumlah yang ideal mencetak skor tertinggi adalah 216 dan skor terendah adalah 72. Saran dalam penelitian ini, didasarkan pada kesimpulan yang diperoleh, adalah pemerintah selayaknya membuka lebih banyak membuka kesempatan agar jumlah peluang usaha dan bekerja bagi wanita di usaha bisnis bunga potong meningkat sehingga menjadi salah satu upaya mengatasi masalah pengangguran wanita dan kemiskinan yang ada di Kota Tomohon.

Kata Kunci : partisipasi, wanita, usaha bunga potong, Desa Kakaskasen II, Kota Tomohon 


\section{PENDAHULUAN}

\section{Latar Belakang}

Di era globalisasi ini, banyak sekali usaha-usaha yang dilakukan guna mendapatkan pendapatan bagi keluarga. Usaha di bidang pertanian pun menjadi salah satu pilihan yang digemari masyarakat. Berkembangnya zaman bukan hanya laki-laki yang melakukan usaha namun wanita juga turut terlibat dalam berbagai usaha dibidang pertanian.

Perkembangan masyarakat dewasa ini memerlukan partisipasi wanita.Dalam transisi ke arah industrialisasi terutama terjadi di daerah perkotaan ternyata bahwa tenaga kerja wanita memegang peranan yang penting dalam perkembangan pertanian, wanita tidak mampu untuk eksis dikarenakan masih adanya penilaian masyarakat terhadap wanita pada sektor pertanian yang masih mendiskriminasi wanita serta asumsi yang menyatakan bahwa kegiatan pertanian merupakan urusan laki-laki yang dinyatakan sebagai pengelola usaha tani adalah suami atau kepala keluarga(Pratiwi, 2007). Hal ini dikuatkan dengan norma dan tradisi yang hidup dalam masyarakat yang mengakibatkan mereka kurang menjangkau sumber-sumber ekonomis (tanah, modal dan tenaga) dan berbagai kemudahan dari pemerintah seperti pendidikan keterampilan, penyuluhan dan pelayanan lain seperti halnya kaum laki-laki, padahal wanita juga memiliki hak-hak asasi selaku wanita.Wanita memiliki kesempatan yang sama dalam berbagai bidang. Wanita mempunyai tanggung jawab yang sama terhadap kehidupan bermasyarakat, berbangsa dan bernegara demi majunya negara ini termasuk didalamnya berpartisipasi dalam bidang usaha pertanian.

Partisipasi wanita di bidang pertanian merupakan sesuatu yang tidak dapatdibantah lagi, banyak sekali penelitian yang sudah membuktikannya.

Di dunia pertanian khususnya pertanian tanaman pangan pembagian kerja antara laki-laki dan wanita sangat jelas terlihat, sehingga dengan adanya spesifikasi pekerjaan antara perempuan dan laki-laki sering di katakan bahwa laki- laki bekerja untuk kegiatan yang banyak menggunakan otot dan wanita bekerja untuk kegiatan yang banyak memakan waktu. Adanya peluang kepada wanita untuk berpartisipasi secara aktif, akan berpengaruh bukan saja terhadap kinerja suatu program, tetapi juga memberdayakan wanita dan menimbulkan rasa kepemilikan (sense of ownership) terhadap suatu sumber usaha. Akses yang lebih baik terhadap sumberdaya juga memberikan kesempatan kepada wanita untuk berkontribusi dalam kegiatan ekonomi produktif.

Di Kota Tomohon dikenal dengan Kota bunga. Banyak sekali usaha bunga yang berkembang di Kota ini, khususnya di Kecamatan Tomohon Utara Kelurahan Kakaskasen II, salah satu usaha yantg berkembang dan diminati oleh banyak warga yaitu usaha bunga potong. Hampir di setiap jalan raya Kakaskasen dapat ditemui usaha bunga potong yang ditekuni warga sebagi sumber mata pencaharian. Menjadi hal yang sangat menarik untuk diteliti bagaimana partisipasi tenaga kerja wanita dalam usaha bunga potong di Kelurahan ini begitu pun dengan laki-laki yang megerjakan dalam usaha bunga potong ini.

\section{Tujuan Penelitian}

Tujuan penelitian mengetahui partisipasi tenaga kerja wanita dalam usaha bunga potong di Kelurahan Kakaskasen II Kecamatan Tomohon Utara Kota Tomohon.

\section{Manfaat Penelitian}

Manfaat dari penelitian ini yaitu:
diharapkan dapat bermanfaat untuk
pengembangan tenaga kerja bunga potong dan
terlebih khusus kepada tenaga kerja wanita di
Kelurahan Kakaskasen II Kecamatan Tomohon
Utara Kota Tomohon dan sebagai masukan,
kajian bagi penelitian selanjutnya.




\section{METODE PENELITIAN}

\section{Waktu dan Tempat Penelitian}

Penelitian ini berlangsung selama 3 bulan mulai dari bulan November 2015 sampai dengan bulan Januari 2016, mulai dari persiapan sampai dengan penyusunan laporan hasil penelitian. Tempat penelitian dilakukan di Kelurahan Kakaskasen II Kecamatan Tomohon Utara Kota Tomohon.

\section{Jenis dan Sumber Data}

Data yang digunakan dalam penelitian ini yaitu data primer. Data primer diperoleh dengan melakukan wawancara langsung kepada responden.

\section{Metode Pengumpulan Data}

Metode pengumpulan data di ambil secara purposive sampling seluruh tenaga kerja wanita lewat wawancara dan pengamatan (observasi) langsung kepada masyarakat yang pemilik usaha bunga yang ada di lapangandengan jumlah semua sebanyak 9 sampel. Pengumpulan data pemilik usaha bunga potong menggunakan kusioner, danturun ke lapangan dengan wawancara secara langsung kepada pemilik usaha bunga potong. Setelah itu di pilih responden dan di sesuaikandengan konsep pengukuran variabel, untuk melihat usaha tenaga kerja wanita dalam bunga potong, dengan mengambil sampel dari pemilik usaha bunga potong di Kelurahan Kakaskasen II Kecamatan Tomohon Utara Kota Tomohon.

\section{Konsep Pengukuran Variabel}

1. Karakteristik dari masyarakat

a. Umur responden adalah(Tahun)

b. Laki-laki dan Perempuan

c. Pekerjaan responden adalah Petani, PNS dan Wiraswasta

d. Tingkat pendidikan adalah SD,SMP,SMA dan S1

e. Partisipasi tenaga kerja wanita dalam usaha bunga potong yaitu melihat keterlibatan wanita dalam melakukan usaha bunga potong di waktu saat penanaman,pemeliharaan,pelaksanaan sampai pada penjualan yang diukur lewat

1. Kehadiran dalam tahap kegiatan penanaman

a. Kurang aktif (3 kali saja dalam seminggu)

b. Aktif (5 kali saja dalam seminggu)

c. Sangat aktif ( 7 hari dalam seminggu)

2. Kehadiran dalam tahap kegiatan pemeliharaan
a. Kurang aktif (3 kali saja dalam seminggu)
b. Aktif ( 5 kali saja dalam seminggu)
c. Sangat aktif ( 7 hari dalam seminggu)

3.Kehadiran dalam tahap kegiatan pelaksanaan
a. Kurang aktif (3 kali saja dalam seminggu)
b. Aktif (5 kali saja dalam seminggu)
c. Sangat aktif (7 hari dalam seminggu)

4. Kehadiran dalam tahap kegiatan Penjualan
a. Kurang aktif ( 3 kali saja dalam seminggu)
b. Aktif (5 kali saja dalam seminggu)
c. Sangat aktif ( 7 hari dalam seminggu)

5. Keaktifan dalam tahap penanaman dalam usaha bunga potong :

a. Kurang aktif : (jarang menyiram, merawat, dan menjaga di tahap ini.)

b. Aktif : (hampir di saat penanaman bunga potong selalu memberikan perhatian untuk menyiram, dan merawat bunga potong dalam tahap ini)

c. Sangat aktif (Setiap saat penanaman bunga potong selalu memberikan perhatian penuh untuk menyiram, membersihkan, dan merawat bunga potong dalam tahap ini)

6. Keaktifan dalam tahap pemeliharaan pada usaha bunga potong :

a. Kurang aktif : (jarang memperhatikan, membersihkan, dan merawat di tahap ini.)

b. Aktif : (hampir di saat pemeliharaan bunga potong selalu memberikan perhatian untuk memperhatikan, membersihkan, dan merawat bunga potong dalam tahap ini)

c. Sangat aktif : (setiap saat pemeliharaan bunga potong selalu memberikan perhatian penuh untuk memperhatikan, 
menyiram, membersihkan, dan merawat bunga potong dalam tahap ini)

7.Keaktifan dalam tahap pelaksanaan pada usaha bunga potong :

a. Kurang aktif : (jarang pelaksanan untuk merangkai, membantu, memikirkan dalam tahap ini)

b. Aktif : (hampir di saat pelaksanaan selalu membantu merangkai dan memikirkan dalam tahap ini)

c. Sangat aktif : (setiap saat pelaksanaan bunga potong selalu saja merangkaikan dan selalu memberikan tambahan strategi untuk penjualan bunga potong dalam tahap ini)

8. Keaktifan dalam tahap penjualan pada usaha bunga potong :

a. Kurang aktif : (jarang di tempat,mempromosikan,dan melayani di tahap ini.)

b. Aktif : (hampir di saat penjualan bunga potong selalu berperan untuk di tempat,mempromosikan,dan melayani bunga potong dalam tahap ini)

c. Sangat aktif : (setiap saat penanaman bunga potong selalu memberikan perhatian serta peran penuh untuk di tempat, mempromosikan, dan melayani bunga potong dalam tahap ini

\section{Analisis Data}

Analisis data dalam penelitian ini digunakan dalam metode analisis deskriptif dan juga mengunakan skala Likert, yaitu dengan jenjang 1(kurang aktif), 2(aktif), 3(sangat aktif). Dengan data yang dihasilkan dari skala Likert dalam analisis ini, maka akan diketahui kemampuan dari tenaga kerja wanita di setiap kegiatan, yaitu penanaman, pemeliharaan, pelaksanaan, dan penjualan.

Analisis terhadap hasil penelitian dibuat dalam skala likert dan daftar pertanyaan kusioner.

S3 = Sangat Aktif

$\mathrm{S} 2=$ Aktif

S1 = kurang aktif

Jumlah skor seluruh pertanyaan = capaian jumlah skor $\mathrm{x}$ jumlah responden $\mathrm{x}$ jumlah pertanyaan

$\mathrm{S} 3=3 \times 9 \times 8=216$
$\mathrm{S} 2=2 \times 9 \times 8=144$

$\mathrm{S} 1=1 \times 9 \times 8=72$

Jumlah skor tertinggi $=216$

Jumlah skor terendah $=72$

Interpretasi nilai 9 rendah

18 cukup

27 tinggi

Tingkat Partisipasi

$=\frac{\text { Jumlah Skor Hasil Pengumpulan data }}{\text { Jumlah Skor ideal }} \times 100$

Dengan Interpretasi nilai

$0 \%-33,3 \%=$ Rendah

$33,4 \%-66,6 \%=$ Cukup

$66,7 \%-100 \%=$ Tinggi

\section{HASIL DAN PEMBAHASAN}

\section{Deskripsi Wilayah Penelitian}

\section{Keadaan Geografis Umum Kelurahan Kakaskasen II}

Kelurahan Kakaskasen II, secara administrasi, termasuk dalam wilayah Kecamatan Tomohon Utara, Kota Tomohon Provinsi Sulawesi Utara. Sedangkan secara geografis, Kelurahan Kakaskasen II terletak pada 1,15 Lintang Utara dan 124,5 Bujur Timur dengan mempunyai luas wilayah sebesar $378 \mathrm{~km}^{2}$ (Matindas dkk., 2010) yang terdiri dari lahan kering berupa tegalan,pekarangan dan lahan tidur seluas 198 ha, lahan sawah seluas 70 ha, kolam seluas 3 ha, serta hutan seluas 52 ha (Soekarya, 2011) dan berbatasan dengan :

Sebelah Utara : Kelurahan Kakaskasen Satu

Sebelah Timur : Gunung Mahawu

Sebelah Barat : Gunung Lokon

Sebelah Selatan : Kelurahan Kakaskasen Tiga

Iklim Kelurahan Kakaskasen II pada umumnya sejuk dengan temperatur udara antara $19^{\circ} \mathrm{C}-29^{\circ} \mathrm{C}$. Topografi Kelurahan ini datar, berbukit dan bergelombang serta letak ketinggianya berada pada $600 \mathrm{~m}$ dari permukaan laut (Matindas dkk., 2010; Soekarya, 2011).

Kelurahan Kakaskasen II dikenal sebagai pusat penjualan bunga potong di Kota Tomohon, bahkan merupakan pemasok utama 
bunga potong di Sulawesi utara (Pangemanan dkk.dalam Mantiri, 2014).

Hal ini dikarenakan luas areal dan produksinya yang besar juga banyaknya masyarakat setempat yang mengusahakan bunga potong. Ada beberapa jenis bunga potong yang di usahakan, antara lain gladiol, aster, krisan, mawar, dan anyelir.

\section{Karakteristik Responden}

\section{Umur Responden}

Tingkat umur mempengaruhi kemampuan seseorang dalam melakukan aktivitas maupun konsep berpikir khususnya untuk tenaga kerja wanita dalam bunga potong.Tenaga kerja wanita yang memiliki umur muda tentunya memiliki kondisi fisik yang lebih kuat, keinginan untuk mencoba hal baru, serta memiliki daya berpikir yang lebih kreatif dibandingkan dengan yang berumur tua. Selain itu, tenaga kerja wanita ini yang telah berumur lebih tua cenderung untuk lebih menjaga kesehatanya. Dari data primer yang di peroleh, usia tenaga kerja wanita dalam usaha bunga potong antara 29-71 tahun. Komposisi umur responden dalam penelitian ini di sajikan pada Tabel 1.

Tabel.1. Jumlah Responden Tingkat Umur

\begin{tabular}{cccc}
\hline No. & $\begin{array}{c}\text { Umur } \\
\text { (Tahun) }\end{array}$ & $\begin{array}{c}\text { Jumlah } \\
\text { Responden } \\
\text { (orang) }\end{array}$ & $\begin{array}{c}\text { Persentasi } \\
(\%)\end{array}$ \\
\hline 1 & $20-30$ & 1 & 11,11 \\
2 & $31-40$ & 6 & 66,66 \\
3 & $41-50$ & 1 & 11,11 \\
4 & $51-60$ & - & - \\
5 & $>60$ & 1 & 11,11 \\
\hline Jumlah & & 9 & 100 \\
\hline
\end{tabular}

Sumber :Data Primer, Januari 2016

Tabel 1 menunjukkan bahwah jumlah responden terbanyak berada pada interval umur 31- 40 tahun yaitu sebanyak 6 orang $(66,66 \%)$. Selanjutnya berada pada interval umur 20-30 tahun, 41- 50 tahun, >60 tahun masing-masing 1 responden.

\section{Pekerjaan Responden}

Jenis pekerjaan sangat mempengaruhi sikap seseorang dalam partisipasi bunga potong. Karena ketika seseorang sudah menemukan pekerjaan yang tepat dengan tingkat pendapatan yang cukup atau lebih untuk memenuhi kebutuhan keluarga, maka ia akan fokus dengan pekerjaanya dan hal ini mempengaruhi seseorang untuk berpartisipasi dalam usaha bunga potong. Tabel 2 menunjukan jenis pekerjaan responden tenaga kerja wanita dalam usaha bunga potong. Tabel 2 menunjukkan bahwa dalam penelitian ini terdapat 3 kategori jenis pekerjaan dari responden, yaitu pegawai negri sipil, wiraswasta, dan ibu rumah tangga kategori wiraswasta merupakan jenis pekerjaan terbanyak dari responden yaitu 6 responden $(66,66)$. Kategori ibu rumah tangga sebanyak 2 responden yaitu (22.22\%) kategori pegawai negri sipil sebanyak 1 orang $(11,00 \%)$.

Tabel.2 Jumlah Responden Jenis Pekerjaan

\begin{tabular}{cccc}
\hline No. & $\begin{array}{c}\text { Jenis } \\
\text { Pekerjaan }\end{array}$ & $\begin{array}{c}\text { Jumlah } \\
\text { Respon- } \\
\text { den } \\
\text { (orang) }\end{array}$ & $\begin{array}{c}\text { Persen- } \\
\text { tasi } \\
(\%)\end{array}$ \\
\hline 1 & Wiraswasta & 6 & 66,66 \\
2 & PNS & 1 & 11,00 \\
3 & Ibu Rumah & 2 & 22,22 \\
& Tangga & & \\
\hline Jumlah & & $\mathbf{9}$ & $\mathbf{1 0 0}$
\end{tabular}

Sumber : Data Primer, Januari 2016

\section{Pendidikan Responden}

Tingkat laku individu atau seseorang sangat dipengaruhi oleh pendidikan yang telah dicapai. Begitu juga pada tenaga kerja wanita tingkat pendidikan atau sangat mempengaruhi partisipasi tenaga kerja wanita dalam usaha bunga potong. Partisipasi tenaga kerja dengan pendidikan tinggi akan cenderung aktif dalam pengelolaan usaha bunga potong. 


\begin{tabular}{cccc} 
Tabel.3. & $\begin{array}{c}\text { Jumlah } \\
\text { Pendidikan }\end{array}$ & Responden & Tingkat \\
\hline No. & $\begin{array}{c}\text { Tingkat } \\
\text { Pendidika } \\
\text { n }\end{array}$ & $\begin{array}{c}\text { Jumlah } \\
\text { Respond } \\
\text { en } \\
\text { (orang) }\end{array}$ & $\begin{array}{c}\text { Persentas } \\
\text { i } \\
(\%)\end{array}$ \\
\hline 1 & \multicolumn{3}{c}{} \\
2 & SMP & 1 & 11,11 \\
3 & SMA & 6 & 66,66 \\
\hline Jumlah & & 2 & 22,22 \\
\hline
\end{tabular}

Sumber :Data Primer, Januari 2016

Tabel 3 menunjukkan tingkat pendidikan responden terbanyak yaitu SMA sebanyak 6 responden $(66,66 \%)$, sedangkan tingkat S1 sebanyak 2 responden $(22,22 \%)$, tingkat SMP sebanyak 1 responden $(11,11 \%)$.

\section{Partisipasi Tenaga Kerja Wanita Dalam Usaha Bunga Potong}

Kelurahan kakaskasen II adalah daerah yang terkenal dengan usaha bunga potong, terdapat 11 usaha bunga potong didaerah ini, dan tenaga kerja adalah masyarakat setempat baik wanita maupun laki-laki.

Partisipasi wanita dalam bidang pertanian sangatlah besar termasuk dalam usaha bunga potong di kelurahan Kakaskasen II penting untuk mengukur partisipasi tenaga wanita dalam usaha bunga potong khususnya di kelurahan Kakaskasen II, dilihat dari keaktifan setiap anggota tenaga kerja mulai dari proses penanaman, pemeliharaan, pelaksanaan bahkan sampai pada proses penjualan.

\section{$\begin{array}{llll}\text { Kehadiran Dalam Tahap } & \text { Kegiatan }\end{array}$}

Kegiatan penanaman dalam penelitian ini adalah proses menanam bunga mulai dari penyiapan bibit baik bibit lokal maupun bibit import yang nantinya akan dijadikan bunga potong. Jenis-jenis bunga yang ditanaam antara lain adalah bunga Krisan, bunga Aster, bunga Radiolen, bunga Andolium. Kehadiran tenaga kerja wanita dalam proses penenaman dapat dilihat pada Tabel 4.

Hasil penelitian ini menunjukkan bawah 44,4\% responden (4 orang) Sangat Aktif dalam tahap penanaman. Sedangkan 55,6\% responden (5 orang) kurang aktif dalam tahap penanaman hal ini dekarenakan dalan tahap penanaman beberapa reponden tdak ikut serta karena ada yang mengurus rumah tangga, dan ada yang mengambil bunga langsung dari petani penanam bunga. Total skor yang diperoleh dari 9 responden pada pertanyaan ini adalah17. Angka indeks Partisipasi mengenai pertanyaan nomor 1 yaitu : $17 / 27 \times 100=62,9 \%$ sehingga interpretasi nilainya tergolong cukup.

\section{Kehadiran Dalam Tahap Kegiatan Pemeliharaan}

Kegiatan pemeliharaan dalam penelitian ini adalah proses pemeliharaan bunga seperti menyiram, memberi pupuk, dan memantau bunga. Yang nantinya akan menjadi bunga potong. Kehadiran tenaga kerja wanita dalam proses pemeliharaan dapat dilihat pada Tabel 4.

Hasil penelitian ini menunjukkan bawah $55,6 \%$ responden (5 orang) Sangat Aktif dalam tahap pemeliharaan, $22,2 \%$ responden ( 2 orang) aktif, dan $22,2 \%$ responden ( 2 orang) kurang aktif dalam tahap pemeliharaan. Total skor yang diperoleh dari 9 responden pada pertanyaan ini adalah 21. Angka indeks Partisipasi mengenai pertanyaan nomor 2 yaitu : $21 / 27 \times 100=$ $77,7 \%$ sehingga interpretasi nilainya tergolong tinggi. Karena pemeliharaan tenaga kerja wanita usaha bunga potong sering terlibat dalam proses pemeliharan penyiraman, dan pemberian pupuk.

\section{Kehadiran Dalam Tahap Kegiatan Pelaksanaan}

Kegiatan pelaksanaan dalam penelitian ini adalah proses pelaksanaan bunga seperti memindahkan bunga, memilih bunga, memotong bunga dan merangkaikan bunga. Yang nantinya akan menjadi bunga potong. 
Kehadiran tenaga kerja wanita dalam proses pelaksanaan ini dapat dilihat pada Tabel 4.

Hasil penelitian ini menunjukan bawah $77,8 \%$ responden (7 orang) Sangat Aktif dalam tahap pelaksanaan, $11,1 \%$ responden ( 1 orang) aktif, dan $11,1 \%$ responden (1 orang) kurang aktif dalam tahap pelaksanaan. Total skor yang diperoleh dari 9 responden pada pertanyaan ini adalah 24. Angka indeks Partisipasi mengenai pertanyaan nomor 3 yaitu : 24/27 x $100=$ $88,8 \%$ sehingga interpretasi nilainya tergolong tinggi. Karena pelaksanaan tenaga kerja wanita usaha bunga potong sering terlibat dalam proses memindahkan bunga, memilih bunga, memotong bunga dan merangkaikan bunga.

\section{Kehadiran Dalam Tahap Kegiatan Penjualan}

Kegiatan penjualan dalam penelitian ini adalah proses penjualan bunga potong seperti menjaga toko dan melayani pelanggan. Yang nantinya akan terjual kepada konsumen. Kehadiran tenaga kerja wanita dalam proses penjualan ini dapat dilihat pada Tabel 4.

Hasil penelitian ini menunjukan bawah $88,9 \%$ responden (8 orang) Sangat Aktif dalam tahap penjualan, sedangkan $11,1 \%$ responden (1 orang) aktif. Total skor yang diperoleh dari 9 responden pada pertanyaan ini adalah 26. Angka indeks Partisipasi mengenai pertanyaan nomor 4 yaitu : $26 / 27$ x $100=96,2 \%$ sehingga interpretasi nilainya tergolong tinggi. Karena penjualan di tenaga kerja wanita usaha bunga potong sering terlibat dalam proses menjaga toko dan melayani pelanggan.

\section{Keaktifan Dalam Tahap Penanaman Dalam Usaha Bunga Potong}

Keaktifan dalam hal ini adalah seberapa sering tenaga kerja wanita terlibat dalam tahap penanaman, dalam hal ini bukan hanya sekedar hadir tapi juga berperan aktif dalam kegiatan-kegiatan didalam proses penanaman. Keaktifan dalam tahap penanaman dalam usaha bunga potong dapat dilihat pada Tabel 5.

Hasil penelitian ini menunjukkan bawah $66,6 \%$ responden (6 orang) Sangat Aktif dalam tahap penanaman, sedangkan $33,3 \%$ responden (3 orang) kurang aktif. Total skor yang diperoleh dari 9 responden pada pertanyaan ini adalah 21. Angka indeks Partisipasi mengenai pertanyaan nomor 5 yaitu : $21 / 27$ x $100=77,7 \%$ sehingga interpretasi nilainya tergolong tinggi. Karena meskipun ada tenaga kerja yang kurang aktif tetapi tenaga kerja wanita usaha bunga potong cenderung sangat aktif dalam keaktifan penanaman.

\section{Keaktifan Dalam Tahap Pemeliharaan Dalam Usaha Bunga Potong}

Keaktifan dalam hal ini adalah seberapa sering tenaga kerja wanita terlibat dalam tahap pemeliharaan, dalam hal ini bukan hanya sekedar hadir tapi juga berperan aktif dalam kegiatan-kegiatan didalam proses pemeliharaan. Keaktifan dalam tahap pemeliharaan dalam usaha bunga potong dapat dilihat pada Tabel 5 .

Hasil penelitian ini menunjukkan bawah $88,8 \%$ responden (8 orang) Sangat Aktif dalam tahap pemeliharaan, sedangkan $11,1 \%$ responden (1 orang) kurang aktif. Total skor yang diperoleh dari 9 responden pada pertanyaan ini adalah 25. Angka indeks Partisipasi mengenai pertanyaan nomor 6 yaitu : 25/27 x $100=92,5 \%$ sehingga interpretasi nilainya tergolong tinggi. Karena tenaga kerja wanita usaha bunga potong sangat aktif setiap kegiatan dalam pemeliharaan.

\section{Keaktifan Dalam Tahap Pelaksanaan dalam Usaha Bunga Potong}

Keaktifan dalam hal ini adalah seberapa sering tenaga kerja wanita terlibat dalam tahap pelaksanaan, dalam hal ini bukan hanya sekedar hadir tapi juga berperan aktif 
dalam kegiatan-kegiatan didalam proses pelaksanaan. Keaktifan dalam tahap pelaksanaan dalam usaha bunga potong dapat dilihat pada Tabel 5 .

Hasil penelitian ini menunjukan bawah $77,7 \%$ responden (7 orang) Sangat Aktif dalam tahap pelaksanaan, sedangkan $22,2 \%$ responden ( 2 orang) aktif. Total skor yang diperoleh dari 9 responden pada pertanyaan ini adalah 25. Angka indeks Partisipasi mengenai pertanyaan nomor 7 yaitu : 25/27 x $100=92,5 \%$ sehingga interpretasi nilainya tergolong tinggi. Karena tenaga kerja wanita usaha bunga potong sangat aktif setiap kegiatan dalam pelaksanaan.

\section{Keaktifan Dalam Tahap Penjualan Dalam Usaha Bunga Potong}

Keaktifan dalam hal ini adalah seberapa sering tenaga kerja wanita terlibat dalam tahap penjualan, dalam hal ini bukan hanya sekedar hadir tapi juga berperan aktif dalam kegiatan-kegiatan didalam proses penjualan. Keaktifan dalam tahap penjualan dalam usaha bunga potong dapat dilihat pada Tabel 5.

\section{Tabel 4. Kehadiran Partisipasi Tenaga Kerja Wanita Dalam Usaha Bunga Potong}

\begin{tabular}{|c|c|c|c|c|c|}
\hline No. & $\begin{array}{c}\text { Alternatif } \\
\text { Jawaban(skor) }\end{array}$ & $\begin{array}{l}\text { Kehadiran dlm } \\
\text { tahapPenanaman } \\
(\%)\end{array}$ & $\begin{array}{c}\text { Kehadiran dlm } \\
\text { tahap } \\
\text { Pemeliharaan } \\
(\%)\end{array}$ & $\begin{array}{c}\text { Kehadiran } \\
\text { dalam tahap } \\
\text { Pelaksanaan } \\
(\%)\end{array}$ & $\begin{array}{c}\text { Kehadiran } \\
\text { dlm tahap } \\
\text { Penjualan } \\
(\%)\end{array}$ \\
\hline 1 & Sangat aktif (3) & $4(44,4 \%)$ & $5(55,6 \%)$ & $7(77,8)$ & $8(88,9)$ \\
\hline 2 & Aktif & - & $2(22,2 \%)$ & $1(11,1)$ & $1(11,1)$ \\
\hline 3 & Kurang aktif (1) & $5(55,6 \%)$ & $2(22,2 \%)$ & $1(11,1)$ & - \\
\hline & Total & $9(100 \%)$ & $9(100 \%)$ & $9(100 \%)$ & $9(100 \%)$ \\
\hline
\end{tabular}

Sumber :Data Primer, Januari 2016

Tabel 5.Keaktifan Partisipasi Tenaga Kerja Wanita Dalam Usaha Bunga Potong

\begin{tabular}{cccccc}
\hline No. & $\begin{array}{c}\text { Alternatif } \\
\text { Jawaban(skor) }\end{array}$ & $\begin{array}{c}\text { Keaktifan dlm } \\
\text { tahap } \\
\text { Penanaman } \\
(\%)\end{array}$ & $\begin{array}{c}\text { Keaktifan dalam } \\
\text { tahap } \\
\text { Pemeliharaan } \\
(\%)\end{array}$ & $\begin{array}{c}\text { Keaktifan } \\
\text { dalam tahap } \\
\text { Pelaksanaan } \\
(\%)\end{array}$ & $\begin{array}{c}\text { Keaktifan } \\
\text { dalam tahap } \\
\text { Penjualan }(\%)\end{array}$ \\
\hline 1 & $\begin{array}{c}\text { Sangat aktif (3) } \\
2\end{array}$ & $6(66,6 \%)$ & $8(88,8 \%)$ & $7(77,8)$ & $8(88,9)$ \\
3 & $\begin{array}{c}\text { Aktif } \\
(2)\end{array}$ & - & - & $2(22,2)$ & $1(11,1)$ \\
\hline $\begin{array}{c}\text { Kung aktif } \\
(1)\end{array}$ & $3(33,3 \%)$ & $1(11,1 \%)$ & - & - \\
\hline & Total & $9(100 \%)$ & $9(100 \%)$ & $9(100 \%)$ & $9(100 \%)$ \\
\hline
\end{tabular}

Sumber :Data Primer, Januari 2016 
Hasil penelitian ini menunjukkan bawah $88,8 \%$ responden (8 orang) Sangat Aktif dalam tahap penjualan, sedangkan $11,1 \%$ responden (1 orang) aktif. Total skor yang diperoleh dari 9 responden pada pertanyaan ini adalah 26.

Angka indeks Partisipasi mengenai pertanyaan nomor 8 yaitu : $26 / 27 \times 100=$ $96,2 \%$ sehingga interpretasi nilainya tergolong tinggi. Karena tenaga kerja wanita usaha bunga potong sangat aktif setiap kegiatan dalam penjualan.

Tabel 6 menunjukkan bahwa terdapat 8 indikator partisipasi tenaga kerja wanita usaha bunga potong dimana pertanyaan 8 mendapat indeks tertinggi yaitu $96,2 \%$. Sedangkan Pertanyaan 1 mendapat indeks partisipasi $62,9 \%$, Pertanyaan 2 mendapat indeks partisipasi $77,7 \%$, Pertanyaan 3 mendapat indeks partisipasi $88,8 \%$, Pertanyaan ke 4 mendapat indeks partisipasi $96,2 \%$, Pertanyaan ke 5 mendapat indeks partisipasi $77,7 \%$, Pertanyaan ke 6 mendapat indeks partisipasi $92,5 \%$, Pertanyaan ke 7 mendapat indeks partisipasi $92,5 \%$, Pertanyaan 8 mendapat indeks partisipasi 96,2\% hampir semuanya mendapat interpretasi tinggi. Pertanyaan 1 mendapat interpretasi cukup karena dibawah 66,6\%. Dan Pertanyaan 2 sampai Pertanyaan 8 mendapat interpretasi tinggi karena di atas $66,6 \%$. Untuk mengetahui tingkat partisipasi tenaga kerja wanita dalam usaha bunga potong di kelurahan kakaskasen II maka perlu di hitung jumlah keseluruhan skor. Dimana sesuai hasil penelitian ini skor mencapai 185. Pada penelitian ini jumlah skor ideal score tertinggi yaitu (216) dan jumlah skor terendah adalah 72 (rendah). Dari data yang di himpun sebanyak 8 pertanyaan yang di ajukan kepada 9 orang responden maka di peroleh total skor 185. Secara persentasi angka indeks partisipasi tenaga kerja wanita dalam usaha bunga potong di kelurahan II terletak pada

\section{Tingkat Partisipasi}

$$
\begin{gathered}
=\frac{\text { Jumlah Skor Hasil Pengumpulan data }}{\text { Jumlah Skor ideal }} \times 100 \% \\
=\frac{185}{216} \times 100 \% \\
=85,6 \%
\end{gathered}
$$

\begin{tabular}{|c|c|c|c|c|}
\hline No & Pertanyaan & $\begin{array}{l}\text { Total } \\
\text { Skor }\end{array}$ & $\begin{array}{c}\text { Indeks } \\
\text { Partisipasi }\end{array}$ & Interpretasi \\
\hline 1 & Kehadiran dalam tahap kegiatan penanaman & 17 & 62,9 & Cukup \\
\hline 2 & Kehadiran dalam tahap kegiatan pemeliharaan & 21 & 77,7 & Tinggi \\
\hline 3 & Kehadiran dalam tahap kegiatan pelaksanaan & 24 & 88,8 & Tinggi \\
\hline 4 & Kehadiran dalam tahap kegiatan penjualan & 26 & 96,2 & Tinggi \\
\hline 5 & $\begin{array}{l}\text { Keaktifan dalam tahap penanaman dalam } \\
\text { usaha bunga potong }\end{array}$ & 21 & 77,7 & Tinggi \\
\hline 6 & $\begin{array}{l}\text { Keaktifan dalam tahap pemeliharaan dalam } \\
\text { usaha bunga potong }\end{array}$ & 25 & 92,5 & Tinggi \\
\hline 7 & $\begin{array}{l}\text { Keaktifan dalam tahap pelaksanaan dalam } \\
\text { usaha bunga potong }\end{array}$ & 25 & 92,5 & Tinggi \\
\hline 8 & $\begin{array}{l}\text { Keaktifan dalam tahap penjualan dalam usaha } \\
\text { bunga potong }\end{array}$ & 26 & 96,2 & Tinggi \\
\hline
\end{tabular}

Tabel 6. Rekapitulasi Jumlah Skor Pengambilan Data, Dan Interpretasi Partisipasi Tenaga Kerja Wanita Dalam Usaha Bunga Potong.

Sumber : Data Primer, Januari 2016 
Berdasarkan hasil analisis menggunakan skala likert maka dapat di ketahui bahwa angka indeks partisipasi tenaga kerja wanita dalam usaha bunga potong kelurahan kakaskasen II berada pada titik $85,6 \%$ dan tergolong tinggi.

\section{Rekapitulasi Partisipasi Tenaga Kerja Wanita Dalam Usaha BungaPotong}

Kesimpulan secara keseluruhan dari penelitian ini tergambar dalam rekapitulasi jumlah skor partisipasi tenaga kerja wanita dalam usaha bunga potong. Kecuali kehadirian dalam kegiatan penanaman yang tergolong cukup maka pada partisipasi kegiatan lainnnya semuanya tergolong tinggi

\section{KESIMPULAN DAN SARAN}

\section{Kesimpulan}

1. Telah di ketahui dalam tahap penjualan tergolong tinggi dalam interpretasinya berdasarkan tingkat partisipasi kehadiran dan keaktifan pada partisipasi tenaga kerja wanita dalam usaha bunga potong di Kelurahan Kakaskasen II Kecamatan Tomohon Utara Kota Tomohon

2. Terlihat dari hasil analisis mengunakan skala Likert maka dapat di ketahui bahwa angka indeks partisipasi tenaga kerja wanita dalam usaha bunga potong di Kelurahan Kakaskasen II berada pada titik $85,6 \%$ dan tergolong tinggi.

\section{Saran}

1. Untuk meningkatkan kebutuhan hidup tenaga kerja wanita usaha bunga potong mereka harus ada usaha lain dalam rangka pendapatan. Ada keinginan dari para tenaga kerja wanita untuk meningkatkan pendapatan dengan membuka usaha di kota lain agar supaya terjangkaunya penjualan dari bunga potong kepada masyarakat.

2. Pemerintah maupun masyarakat setempat lebih mengiatkan partisipasi wanita dalam usaha bunga potong sehingga mengurangi pengangguran di Kota Tomohon.

\section{DAFTAR PUSTAKA}

Damandiri.(2010). www.damandiri.or.id/file/i rahmychalidunhasbab4.pdf diakses pada tanggal 16 Mei 2015.

Ihromi, T. O. (2002). "Wanita Sebagai Penerus Nilai-nilai Kepada Generasi Muda"Prisma, No. 5, hal.72 dalam Laporan Penelitian Kelompok Studi Wanita UI 1990.

Kantor Menteri Negara Urusan Peranan Wanita. (2001). Analisis Studi Wanita Indonesia. Jakarta.

Mantiri R,(2014). Kapabilitas Dinamis Kelompok Tani Barameji Di Kelurahan Kakaskasen II Kecamatan Tomohon Utara. Skripsi. Fakultas Pertanian - Sosial Ekonomi Universitas Samratulangi. Manado.

Matindas, L., Bahtiar, dan A. Turang. (2010). Pengembangan Bunga Krisan Dalam Perspektif Agribisnis Di Kota Tomohon (Kasus Kelurahan Kakaskasen Dua). BPTP SULUT. Manado.

Mayling, Oey G.dkk. 1999. Perempuan Indonesia Dulu dan Kini. PT Gramedia Pustaka Utama, Jakarta.

Mosse, J. C. 1999. Gender. Editor: Hartian Silawati, Rifka Annisa Women's Crisis Centre dengan Pustaka Pelajar. Yogyakarta. Terjemahan dari: Half the World, Half a Chance An Introduction to Gender and Development.

Pratiwi, N. 2007. Analisis Gender pada Rumah tangga Petani Monokultur Sayur.Kasus Desa Segorogunung, Kecamatan Ngargoyoso, Kabupaten Karanganyar.

Ridwan, (2012). Pengantar Statistika Sosial. Bandung. Alfabeta

Sajogyo,Pudjiwati.(2000). Peranan Wanita Dalam Perkembangan Ekonomi. Yayasan Obor Indonesia: Jakarta

Soekarya, T. (2011). Peningkatan Ekonomi Kerakyatan Melalui Pengembangan Desa Wisata : Suatu masukan untuk Pengembangan di Kakaskasen Dua, Tertitip dan Punten. Kementrian Kebudayaan Dan Pariwisata. Jakarta

Wiliam, D. (2003). Tenaga kerja menurut UU No. 13 tahun 2003 Bab 1 pasal 1 ayat 2.: Center for International Forestry Research. 